\title{
Arte Pará: etnografia e interpretação em um salão de artes visuais na Amazônia
}

Arte Pará: ethnography and interpretation at a visual arts exhibition in the Amazon

John Fletcher ${ }^{\star}$

*Universidade Federal do Pará - Belém, PA, Brasil coustonjf@gmail.com

https://orcid.org/0000-0002-5465-5278 


\title{
Resumo
}

O presente trabalho traz relatos etnográficos sobre experiências com artistas, curadores, organizadores e técnicos na montagem do salão Arte Pará, entre os anos de 2012 a 2015, realizados na cidade de Belém. Parte integrante de uma pesquisa de doutorado, este recorte se baseia em premissas metodológicas sincrônicas e dialógicas, a partir de autores como Vincent Crapanzano e James Clifford, problematizados por aportes de pensamentos de Walter Mignolo, Eva Marxen, Beatriz Sarlo, Homi Bhabha e Johannes Fabian, dentre outros. Desse modo, com o intuito de expor um olhar mais crítico sobre nosso presente assimétrico, essa pesquisa visa a conferir outras dimensões interpretativas para a dinâmica geral da experiência humana.

Palavras-chave: artes visuais; Arte Pará; Amazônia; etnografia.

\begin{abstract}
The presente paper brings ethnographic reports on experiences with artists, curators, organizers and technicians in the assembly of the Arte Pará exhibit, between the years of 2012 to 2015, held in the city of Belém. An integral part of a doctoral research, this clipping is based on synchronic and dialogical methodological premises from authors, such as Vincent Crapanzano and James Clifford, problematized by contributions of thoughts by Walter Mignolo, Eva Marxen, Beatriz Sarlo, Homi Bhabha and Johannes Fabian, among others. Thus, in order to expose a more critical view of our asymmetric present, this research aims at conferring other interpretative dimensions to the general dynamics of human experience.
\end{abstract}

Keywords: visual arts; Art Pará; Amazon; ethnography. 


\section{Considerações iniciais ${ }^{1}$}

Ao pararmos para refletir acerca dos salões de artes visuais no exterior, em grande medida pertencentes a algumas das primeiras experiências museais debatidas e problematizadas hoje (Julião, 2006; Pomian, 1984), destaco que os mesmos têm algumas de suas origens ligadas às academias de Belas Artes, já no século XVIII, com uma expansão significativa durante o século XIX e XX (Alvim; Branco; Rocha, 2007). No caso do Brasil,, esta proposta de visibilidade artística, por meio de exposições públicas, ocorreu a partir de 1840, com a Exposição Geral da Academia Imperial de Belas Artes, sob direção de Felix Émile Taunay, filho de Auguste Taunay, sendo este último um dos nomes que compôs a famosa Missão Artística chefiada por Jacques Lebreton (Lourenço, 1999; Moreira, 2007). O intuito da missão chefiada por Lebreton, vale acrescentar, com a consequente instituição da Exposição Geral da Academia Imperial, foi o de alinhavar artisticamente a cidade do Rio de Janeiro, não somente em termos museais, à posição de capital do império português, isto com a vinda da corte de D. João ao Brasil na primeira metade do século XIX (Luz, 2006; Pereira, 2010).

Esses salões artísticos, geralmente apresentados em equipamentos culturais para familiarizar seus visitantes com os critérios acadêmicos, os assuntos em voga e os estilos desenvolvidos por seus participantes, igualmente estabeleceram diferentes modos de parceria entre as suas edições e as críticas de arte de então, e implementaram, até certo ponto com êxito, influência na carreira de artistas, na visibilidade de obras de arte e nos discursos históricos que estavam coniventes com interesses, na maioria das vezes, hegemônicos (Alvim; Branco; Rocha, 2007; Julião, 2006) - isso, pelo menos, antes dos debates em torno das consequências ligadas ao "Salão dos Recusados" (Salon des Refusés), na Paris de 1863.

1 Agradeço à Capes pela concessão da bolsa durante a realização do doutorado, aos professores Drs. Ernani Chaves (PPGA/UFPA) e Agenor Sarraf (PPGA/UFPA) pela orientação e coorientação, respectivamente, e à professora Dra. Jane Felipe Beltrão (PPGA/UFPA) pelos preciosos ensinamentos.

2 É válido destacar também, a título de primeira realização oficial, ainda que com características particulares, a exposição pública de arte organizada por Jean-Baptiste Debret em 2 de dezembro de 1829 (Pereira, 2010). 
No caso do Arte Pará, salão paraense e localizado na esteira do que convenhamos chamar de contemporâneo, ${ }^{3}$ temos um projeto idealizado e capitaneado pelo jornalista e presidente do, então, Grupo Liberal, ${ }^{4}$ Rômulo Maiorana, que passou a ter grande parte de sua ocorrência ${ }^{5}$ (de 1996 a 2015) no Museu Histórico do Estado do Pará (MHEP), dentre outros equipamentos culturais, não somente belenenses, mas intermunicipais. De alguma forma interligado aos contextos iniciais deste artigo, a ocorrência anual e ininterrupta do salão revelou, com a sua primeira edição no ano de 1982, um contraditório papel para se (re)construir outras faces das Amazônias ${ }^{6}$ após o período da ditadura militar - com destaque para a Amazônia Paraense -, e esteve alinhado também a ideais integracionistas, a partir de uma tentativa reincidente de fortalecimento artístico regional em relação ao eixo Sul-Sudeste (ver mais em Fletcher; Sarraf; Chaves, 2017).

Para o caso do presente trabalho, um recorte ${ }^{7}$ de uma pesquisa de doutorado desenvolvida entre os anos de 2012 a 2015, trabalhei com uma metodologia

3 Parto da ideia de contemporâneo como um campo de disputas pelo reconhecimento sociocultural, pelas autoafirmações étnicas e indenitárias e pelo questionamento da concepção das histórias e dos dispositivos os quais construíram narrativas excludentes ou silenciadas (Albán, 2011).

4 O Grupo Liberal é um conglomerado de mídia brasileiro, fundado em 1966, e representa o maior grupo em comunicação do estado do Pará, sendo também um dos maiores do Brasil e grande afiliado à Rede Globo através da Rede Liberal. Após a morte de seu fundador, Rômulo Maiorana, em 1986, passou a ser chamado de Fundação Rômulo Maiorana. As Organizações Rômulo Maiorana são grandes rivais do Grupo RBA de Comunicação, pertencente ao político Jáder Barbalho, e possuem, no governo do estado, ligado ao partido do PSDB, o seu maior cliente (ver mais em Pinto, 2013).

5 Deve-se mencionar, todavia, que o percurso inicial do Salão se remete ao prédio de $O$ Liberal, com sua mostra de artes plásticas, e à Galeria da Residência Maiorana, com a mostra de fotografias. Com o passar dos anos, outros e maiores espaços foram adicionados ao contexto de realização do salão, ao passo que os primeiros foram destituídos (Fletcher; Sarraf; Chaves, 2017).

6 Devemos atentar ao fato de que a Amazônia como região não pode ser pensada como aquela somente atrelada ao vale do rio Amazonas, pois dentro dela também se considera o vale e o transcurso do Orinoco e seus afluentes, a Orinoquia, que desemboca no delta Amacuro, na Venezuela; incorporando a conexão entre ambos, o Casiquiare, os contrafortes da Cordilheira dos Andes, região chamada de Amazônia Andina, mais o Acre boliviano, o qual tem a cidade de Trinidad como grande emblema histórico (Pizarro, 2012).

7 Devo informar, por conseguinte, que este recorte traz como foco minhas experiências etnográficas durante a montagem e abertura do Arte Pará. Também desenvolvi esse mesmo tipo de ação no decurso do salão, que ocorre até a primeira semana de dezembro de todo ano. 
de interpretação das exposições do Arte Pará, com o uso de uma abordagem etnográfica sincrônica e dialógica (ver Clifford, 1998; Crapanzano, 1991; Fabian, 2006; Mignolo, 2003; Tedlock, 1986), capaz de evidenciar quais suas negociações com artistas, projetos visuais e equipamentos culturais na Amazônia. Esta outra forma de aproximação minha de sua concretização como evento tratou de ratificar uma postura capaz de dirimir a autoridade do antropólogo-autor, algo buscado pela incidência das vozes de outros, ainda que mediadas/editorializadas pela minha escrita, bem como um posicionamento mais orgânico e pertencente ao que a antropologia apresentou como o being there (o estar lá), ato diferente da chamada experiência de cartão postal, mas, acima de tudo, apresentação do real e verbalização da vitalidade, com suas especificidades de alto teor sígnico (Geertz, 2009).

Para um aprofundamento desses aspectos metodológicos, certas exemplificações com algumas das obras de arte que fizeram parte desse percurso do Arte Pará foram estabelecidas, e que, por serem vozes sociais (Gell, 1998), rascunharam indicativos convergentes aos desenhos curatoriais pensados pelo salão para construir um roteiro mais ou menos coeso de relações culturais entre local e global. Essas exemplificações com obras participantes, igualmente alicerçadas por diálogos entre a antropologia e o estudo da imagem, conferiram um andamento em que elas também foram tidas como informantes capazes de iluminar descrições inteligíveis para falar sobre a regularidade de tempos e espaços, sem dirimir particularidades.

O salão Arte Pará, mesmo ante à pequena quantidade de pesquisas acadêmicas, é um marcador para as experiências visuais feitas e apresentadas institucionalmente em Belém, com espaço na mídia e referencial para artistas e curadores, não somente locais. E observado o fato da própria pesquisa antropológica ter ainda discretas relações com práticas artísticas institucionais e recentes, esse evento aqui é tomado, em muitos aspectos de maneira inaugural, como um campo fecundo para investigações e análises em torno de suas narrativas/negociações conceituais e curatoriais, tecidas plurivocalmente, por meio de agenciamentos transculturais, em uma metrópole e, por extensão, em circuitos da região amazônica. 


\section{Arte e processos globais}

E somos só esta vã escrita

Nosso riso-risco contra um espelho, praia

Que nos inverte e desescreve

disSOlVENDO-NOS

Max Martins

A trajetória desse acercamento, no caso, iniciou-se na tarde do dia 10 de outubro de 2012, após uma série de negociações mediadas pelo professor e curador Dr. Orlando Maneschy junto à comissão de organização do Arte Pará. Esse processo de negociações, que já vinha sendo tratado desde o começo do primeiro semestre do referido ano, consistiu em preparar os organizadores do evento para as ações intencionadas por essa etapa menos distanciada de minha pesquisa, portanto dentro do espectro da observação participativa.

Foi por volta do começo da tarde daquele dia em questão que obtive o sinal verde para minha entrada no MHEP e na montagem da $31^{\mathrm{a}}$ edição do salão, autorização essa efetivada por Daniela Sequeira, uma das coordenadoras gerais do evento. Contra algumas de minhas expectativas, Daniela foi extremamente acessível e interessada pela ação antropológica proposta e mencionou, inclusive, que já estava a par da minha tese, por conta da mediação de Orlando Maneschy e por conhecer o trabalho de meu professor e orientador, Dr. Ernani Chaves.

Quando cheguei ao local principal de montagem do evento, referência, inclusive, para o calendário anual, então, do museu - isso após enfrentar um trânsito terrível, já que a cidade estava efervescente em virtude do Círio de Nazaré, evento que iria ocorrer no domingo seguinte -, fui cordialmente recebido pelos curadores da exposição daquele ano: Paulo Herkenhoff, em sua terceira trajetória ${ }^{8}$ na curadoria geral do evento, e Armando Queiroz, curador

8 Paulo Herkenhoff, emblemático artista e curador do Espírito Santo, componente de uma das primeiras gerações de videoartistas no país, possui uma experiência com o Arte Pará desde 1987. Sua inserção curatorial, não obstante, se remete a um primeiro intervalo de anos, entre $\rightarrow$ 
adjunto, ambos meus conhecidos de outras exposições e episódios em torno das artes visuais em Belém. Paulo foi quem, mais especificamente, falou-me de sua chegada à capital paraense na madrugada do dia anterior, terça-feira, dia 9 de outubro, para a montagem e consequente trabalho durante o dia que se sucedeu. E pelo que pude perceber, a organização estava com uma agenda tranquila naquela quarta-feira, não somente pelo planejamento prévio para a chegada de Paulo - a pintura das salas expositivas do museu, de acordo com sua escolha em diálogo com Roberta Maiorana, diretora executiva da Fundação Rômulo Maiorana -, como por uma antecipação da disposição das obras em seus nichos arranjados, frente a um plano/croqui elaborado pelos curadores. Conforme eles também me relataram, este pré-arranjamento ${ }^{9}$ foi facilitado pela familiaridade que já possuíam com o espaço museal.

Um dado que me foi logo apreensível após minha chegada se relacionou com o pressuposto temático flexível e processual, para não fechar o evento com um mote muitas vezes desestimulante para os artistas - pressuposto, por sinal, já praticado no ano anterior do Arte Pará (2011), pela curadoria de Ricardo Resende. Segundo ratificado pelo próprio catálogo, publicado algum tempo depois, a mencionada edição de 2012 optou por trazer, visualmente, abordagens sobre os desafios da cultura contemporânea em suas tensões entre sensualidade e racionalidade, fricções no cotidiano e perplexidades do sujeito (Maiorana et al., 2013). E de acordo com o texto do curador, presente tanto nas paredes da exposição quanto na publicação do evento, os artistas convidados, mais especificamente, foram os que ganharam o papel de firmar,

$\rightarrow 1990$ e 1997 (Fletcher; Sarraf; Chaves, 2017), sucedida por outro intervalo, já entre 2005 e 2007. Seu retorno à curadoria do salão ocorreu em 2012.

9 Armando Queiroz, artista e curador paraense, foi quem me relatou mais sobre o processo que Herkenhoff teve para pensar acerca da disposição inicial das obras. Nesse caso, ele mesmo, Herkenhoff, e Roberta Maiorana fizeram um pré-projeto das relações entre os selecionados e convidados ainda em São Paulo. Tal pré-projeto serviu para que se verificasse, na montagem, se tal disposição ainda seria a ideal - e, ao que tudo indicava, as modificações foram muito poucas, sendo a maior ocorrida com a sala de Alberto Bitar, já que, antes, o artista se encontrava em uma distinta, mas que não parecia de acordo com sua poética, por conta de ser um espaço intermediário, de passagem, e que eliminava um maior silêncio que a sua obra pedia. 
de maneira mais explícita, esse eixo conceitual proposto. Esses convidados, portanto, articulados para denotar "[...] o lugar do artista nos processos da sociedade global e a necessidade do reconhecimento da natureza intrínseca dos paradigmas específicos de cada comunidade" (Herkenhoff, 2013, p. 6), delinearam um princípio ciente das transformações pelas quais o mundo vinha passando e insinuaram uma atenção para que o salão respondesse a esse contexto dinâmico e interconectado.

No que concerne a esse grupo de artistas convidados, mais diretamente, identifiquei que ele foi mesclado tanto por nomes locais - destaque para Berna Reale (PA) e para Guy Veloso (PA) -, quanto por de outros estados - destaque para Paulo Nazareth (MG), que recebeu bastante atenção com seus vídeos, fotografias, reproduções, sendo estas últimas vendidas na abertura do salão por valores simbólicos; Rodrigo Braga (PE), por apresentar uma série de fotografias, Desejo eremita; e para Delson Uchôa (AL), com suas performances orientadas para a fotografia, em plena caatinga brasileira, repleta de inserções de guarda-chuvas de mão de obra barata, de maneira a construir paisagens pictóricas surreais. Esse grupo de nomes estabelecidos do cenário das artes visuais concretizou uma coluna vertebral curatorial, capaz de conceder aos artistas convidados um papel expográfico diretor, diferente do atribuído aos artistas selecionados.

O curador Herkenhoff foi quem ainda abordou como o Arte Pará havia se modificado desde suas primeiras edições (já que ele, Paulo, estava presente, mesmo em sua fase inicial), edições as quais tinham partido de um arranjo, inclusive, mais despojado, até o estágio atual, mais profissional e respeitado. Quando questionado por mim acerca da atual proporção da mostra, destacou a expansão primeira do evento em virtude das mudanças rápidas pelas quais o cenário artístico paraense tinha passado - expansão que resultou no reconhecimento artístico de muitos nomes locais para outros eixos do país e do exterior, e também foi aquecida pela vinda de vários nomes estabelecidos no cenário artístico nacional -, ao passo que aquela montagem, com seus 25 selecionados, um número enxuto em sua opinião, privilegiaria uma qualidade que, muitas vezes, seria questionável se o número de obras para um evento como aquele se apresentasse alto.

A sua satisfação com as escolhas do júri de seleção naquele contexto - júri por ele selecionado e composto por Alexandre Sequeira, artista e professor do 
curso de artes da UFPA; Yuri Firmeza, artista plástico cearense; Clarissa Diniz, curadora recifense; e Delson Uchôa, artista plástico alagoano -, pareceu-lhe inspiradora. Nesse sentido, Herkenhoff não poupou esforços para mostrar selecionados e a exposição de seus trabalhos pelas salas do prédio no qual estavam dispostas. Igualmente coerente a esse desenho da exposição, ademais, foi observar a sua atenção aos espaços de respiração entre cada uma das proposições artísticas - a distância, mais precisamente, entre umas e outras, para que não surgissem interferências, sobreposições não intencionais, etc. -, bem como as relações/diálogos que cada uma podia estabelecer com as demais ao seu redor e com as cores definidas para cada uma das salas do museu - cores pensadas como alternativa de imersão sensorial e harmonia estética, tentativa de quebra parcial com a presentificação do prédio histórico.

O diálogo entre Paulo Herkenhoff e eu sobre o Arte Pará daquele ano, cujo tom informal e deliberadamente pensado por mim como algo para além das amarras de uma entrevista com perguntas estruturadas - conforme apresentado por Mignolo (2003) e inspirador para minha abordagem mais específica-, ainda ganhou outra profundidade. Soube, por exemplo, que Herkenhoff buscou ativar reflexões sobre os mais diversos tipos de deslocamentos geográficos e psicológicos, de maneira que se tornou paradigmático conceder, junto ao júri, no dia seguinte, o Grande Prêmio ao Grupo Empreza, formado por professores e alunos da Universidade Federal de Goiás e ganhador de grande destaque no cenário artístico nacional. O Grupo tem apresentado, como significante, o corpo e desenvolve performances em que os seus limites físicos são colocados à prova, em uma articulação conceitual sobre os conflitos do homem com seu entorno. Foi através das performances orientadas para fotografia, presentes no Arte Pará daquele ano, que o Grupo fez visualizar o instante fugidio no qual os corpos de alguns de seus componentes em deslocamento pareciam se fundir no ar, uma espécie de convergência de saltos (Figura 1), polissêmica metáfora para o entendimento do deslocamento/ migração como algo também composto por confrontos e (im)permanências (ver também Maiorana et al., 2013). 


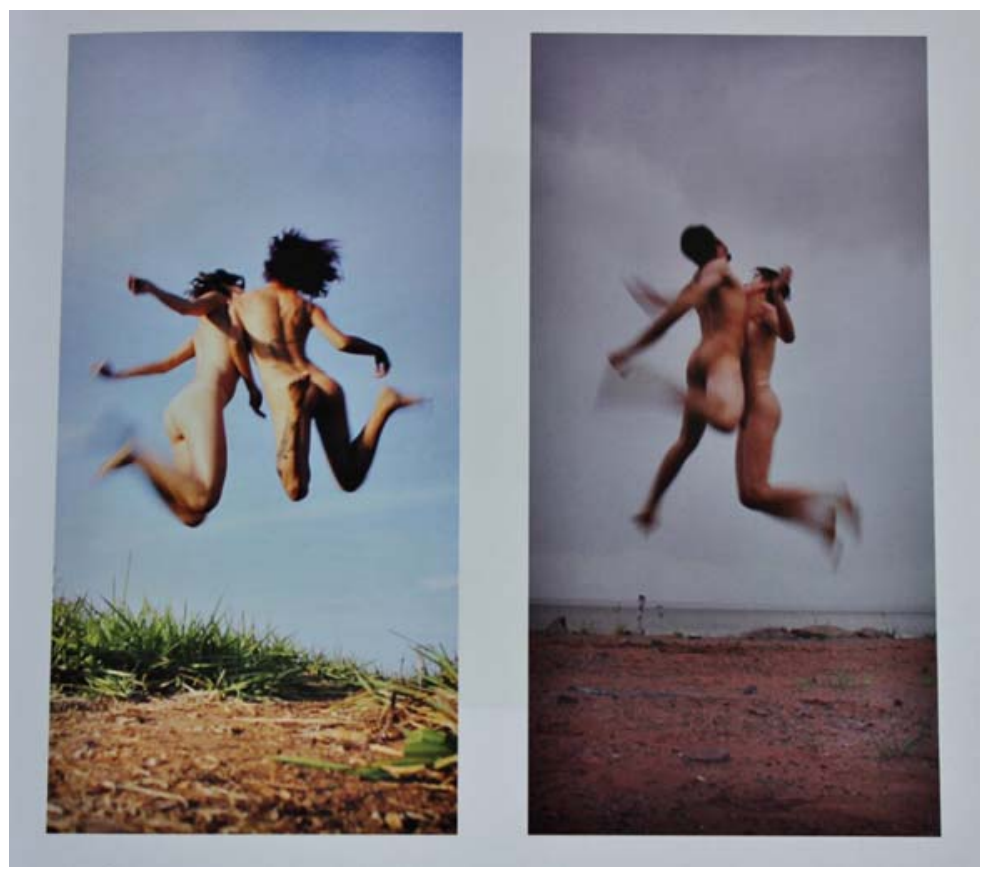

Figura 1. Duas das imagens resultantes da performance orientada para fotografia, Impenetrabilidade [políptico], apresentada pelo Grupo Empreza para o Arte Pará 2012 (foto do autor).

Pelo fim daquele dia, quando fui deixar Paulo em seu hotel, ganhei maior conhecimento da distribuição do salão pelos outros espaços museais da cidade: 0 Museu de Arte Sacra, com a exposição do artista convidado Guy Veloso; a Casa das Onze Janelas, com obras da artista homenageada Paula Sampaio (PA); e o prédio da Rocinha, dentro do Museu Paraense Emílio Goeldi, com fotografias também de Paula Sampaio e objetos recolhidos durante as peregrinações do artista Paulo Nazareth. Desse modo, frente às reordenações do Arte Pará por espaços expositivos e institucionais da cidade somente (sem fazer uso do próprio espaço público, como em outras edições), uma hipótese que me ficou bastante em mente naquele momento, ainda mais em vista de sua reconfiguração em uma tônica mais formalista, esteve ligada ao que Beatriz Sarlo (1993) destacou como a problematização de um novo público e novas formas de consumo ante o acirramento dos múltiplos processos globalizadores. Talvez por primar pela busca por 
semanticidades intensivas e uma organicidade formal, visto o acercamento de poéticas fragmentárias, o Arte Pará de 2012 enfrentou um momento de reafirmar equipamentos de difusão do evento na cidade de Belém. Uma inegável e crescente estruturação de novos fruidores, muitos deles criados com tecnologias de informação recentes e a partir do privilégio da instantaneidade em detrimento dos tempos locais (ver também Mantecón, 1993), trazia desafios paradigmáticos aos horizontes do salão. Conseguiriam eles êxito ante essa realidade?

No segundo dia de minha inserção no processo de montagem do Arte Pará 2012, fui recebido pelo amigo e artista Alberto Bitar. O conjunto de fotografias de Bitar, podemos elencar, Completude, da série Sobre o vazio (Figura 2), foi um dos mais bem-sucedidos marcadores a externar o ensejo curatorial de Herkenhoff para a presente edição. O próprio curador propôs que a apresentação das fotografias de Bitar emulassem um estágio de mudança - estágio esse evocado pelo teor conceitual das imagens -, de maneira que elas não foram penduradas como de costume, mas somente empilhadas próximas às paredes.

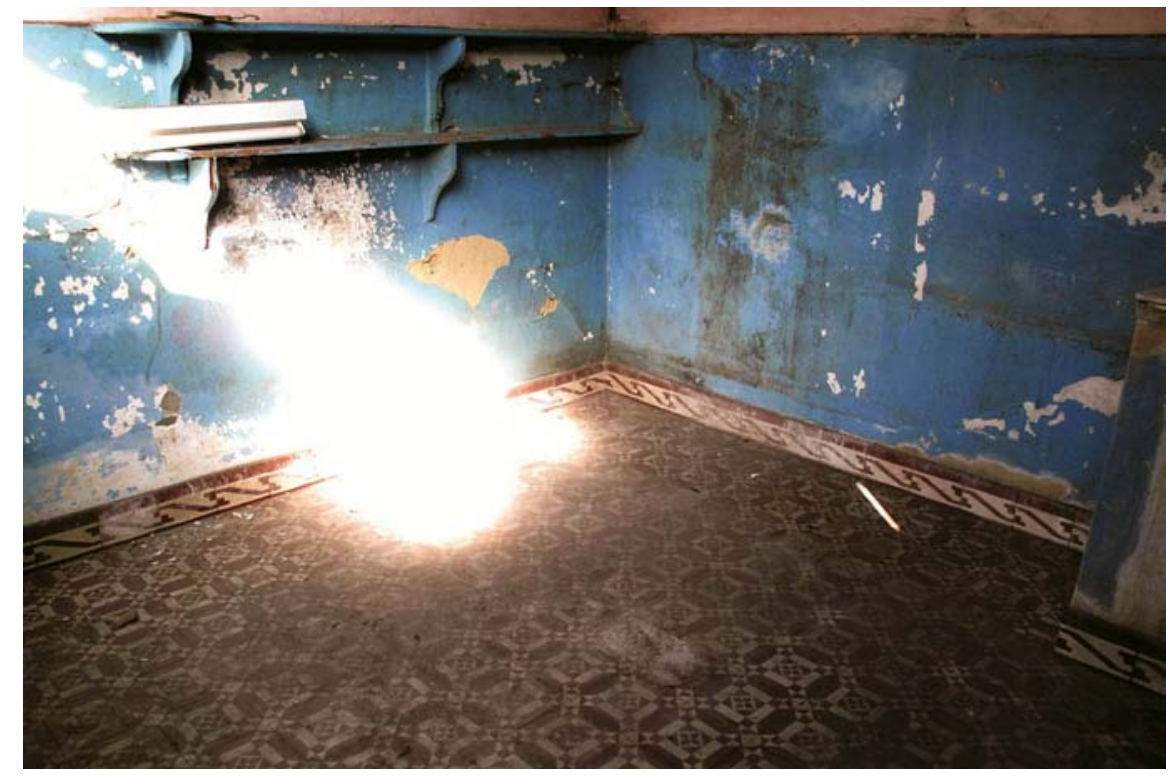

Figura 2. Uma das imagens a compor Completude, da série Sobre o vazio, de Alberto Bitar (Maiorana et al., 2013). 
Ao tomar uma das imagens a compor Completude, produzida pela experiência do artista de fotografar sua antiga moradia, já vazia - a série também apresentou imagens de sua nova moradia, igualmente desocupada, antes da chegada de sua mobília -, um emparelhamento com as análises do filósofo Georges Didi-Huberman (2012) fez-se deveras possível. Por estabelecer que a imagem não seria um simples corte praticado no mundo dos aspectos visíveis, mas uma impressão, um rastro, um traço visual do tempo que quis tocar, acrescido de outros suplementares, as apreciações do supracitado filósofo mostraram-se capazes de ajudar a compreender a simultaneidade de cronologias fatalmente anacrônicas, íntimas, melancólicas e heterogêneas, firmadas pelo clique de Alberto Bitar.

Aliada a essa noção de momentos simultâneos, não se pode deixar de destacar o intuito que a imagem do fotógrafo possuiu de tocar a transitoriedade do real - algo diferente de revelar algum tipo de verdade. Espécie de mediadora entre a vida como impossibilidade de aprisionamento e o discurso sobre a vida como opção alternativa de contato, sua presentificação no salão explicitou grande articulação com o que "[...] os pobres mortais inventam para registrar seus tremores (de desejo e de temor) e suas próprias consumações" (Didi-Huberman, 2012, p. 210) - daí, sob os argumentos do filósofo em questão, a impossibilidade de se falar de imagens sem falar de incêndios e de suas consequentes cinzas, transformações.

Pertencente ao território das sobrevivências suplementares - cinzas de vários braseiros, mais ou menos ardentes -, território esse composto por tempos desunidos por lacunas, a série de Bitar firmou-se por uma dolorosa reflexão sobre o deslocamento como produtor de chagas, discrepâncias e solidão. Componente de uma estratégia de suspensão desconcertante da capacidade de lhe atribuir sentido imediato, sua permanência, quer seja na memória fotográfica, quer seja na sensível disposição de Paulo Herkenhoff para o Arte Pará, prefigurou uma estratégia de destituir o conformismo da tradição de se capturar uma imagem, de maneira a fazer dessa destituição uma forma bem-aventurada e iconoclasta de anunciar incêndios e novas consciências sobre a imagem.

No prosseguimento de meu trabalho etnográfico, também me aproximei do artista alagoano e membro do júri daquele Arte Pará, Delson Uchôa. Ele estava tentando achar uma solução para o atraso da remessa com suas fotografias para a exposição - às 13h daquele dia, elas ainda se encontravam em São Paulo -, 
de forma que Herkenhoff propôs, como alternativa provisória, a projeção de algumas imagens ${ }^{10}$ dessa série sua nas paredes do salão. Infelizmente, como ficou comprovado depois, esse plano de projeções teve de ser cancelado, já que a gravação das imagens, feita em um formato próprio pelo notebook Mac de Delson, não deu certo no aparelho leitor de DVD, incompatível tecnologicamente. Por conseguinte, já que não havia qualquer técnico em informática especializado para solucionar tal desajuste no evento, e tendo em vista a confirmação da não chegada a tempo da remessa com as fotografias de São Paulo por conta de uma greve nos Correios, a Fundação Rômulo Maiorana providenciou a impressão e colagem em PVC dessas imagens localmente. E por não haver serviço, até aquele momento, de impressões fotográficas em fine art, caso não semelhante com as imagens que estavam presas em trânsito de postagem, o resultado estético de algumas impressões ficou muito abaixo das expectativas, mas foi tomado como solução para aquele imbróglio - as imagens provisórias em PVC ficaram somente escoradas na parede, rentes ao chão, sem que comprometessem a pintura, infortúnio que ocorreria caso fossem coladas e, posteriormente, substituídas.

Outra significativa proximidade de bastidores que também pude ter foi com o amigo e artista Victor de La Rocque, que estava empenhado em montar a apresentação de sua performance selecionada para uma videoinstalação, O Senhor é meu pastor e nada me faltará. Fiquei sabendo de certos contratempos sofridos por conta de sua necessidade de encontrar aparelhos televisores de tubo para compor a sua obra - esses aparelhos, juntos, estariam dispostos aleatoriamente no jardim interno do museu, durante a abertura da exposição, e no corredor lateral a esse jardim, nos dias subsequentes. Todavia, Victor me deixou a par da falta de apoio do diretor do MHEP, já que este tinha cinco aparelhos ideais em sua reserva e que não estavam sendo utilizados - o mencionado senhor mostrou uma falta de confiabilidade para com o evento da fundação no que concerne ao empréstimo dos equipamentos do próprio museu, embora ciente de que eles não sairiam daquele local-, além de que esse mesmo diretor mostrou uma resistência para que o artista dispusesse os aparelhos em cima

10 Para minimizar aquela intempérie, Delson, fortuitamente, carregava consigo seu arquivo de imagens recentes. 
do gramado do jardim supracitado, pois, em suas alegações, esse gramado era tombado como patrimônio histórico e não deveria sofrer qualquer tipo de dano.

Um último acercamento ainda ocorreu com o curador adjunto Armando Queiroz. Foi ele quem pôde destacar que sua atuação na curadoria paralela procurava não somente formas de otimizar os contatos com os artistas convidados locais, como também visava a estabelecer pré-negociações infraestruturais antes da montagem com os próprios espaços museais. Em virtude de ter ficado mais à frente da mostra de Paula Sampaio na Casa das Onze Janelas, algo, inclusive, que também lhe possibilitou um papel atuante e muito mais livre na própria montagem da exposição no MHEP, Queiroz ainda fez um paralelo com seu processo de envolvimento como curador assistente no Arte Pará 2011, cuja curadoria foi assinada por Ricardo Resende. Foi nesse ano de 2011, mais especificamente, que, além de ajudar com a montagem das salas do artista convidado Orlando Maneschy, ganhou grande liberdade e autonomia para ser responsável por uma triagem mais apurada em torno das obras que compuseram a Sala Ver-o-Peso. ${ }^{11}$

Abordamos, no andamento de nossa conversa, outros aspectos mais delicados, caso de alguns vícios da produção visual paraense, sendo eles vastamente alimentados também pelo próprio salão Arte Pará, já que muitos trataram de tomá-lo como ponto de confirmação de trajetórias artísticas. De acordo com Queiroz, haveria, nesse enredo anual do evento, um efeito colateral que trazia dificuldades ao fortalecimento artístico local, efeito esse que parecia inibir parte do desenvolvimento de ações entre profissionais-pares para fomentar circuitos independentes na produção de Belém, ou mesmo para apoiar produções visuais menos sedutoras e não feitas para vitrines do que se convencionou especular sobre a arte da virada do século XX para o XXI. O curador destacou, por conseguinte, que o rigor de qualidade do evento passou a afastar uma diversidade de vozes, como se o salão tivesse se tornado escravo de seus próprios parâmetros formais. Esse era um pressuposto formal, portanto, que tratou de gerar empecilhos a modos de autenticidade menos espetaculares, ao empoderamento de novas representatividades locais e a uma política mais ampla sobre outras formas de conscientização artística na região.

11 Esta sala trouxe a presença de 47 artistas convidados, de maneira a compor 45 projetos artísticos a tocar os imaginários e as estéticas encontradas no mercado do Ver-o-Peso, em Belém. 
É presumível que o papel da organização do evento não necessitaria ter qualquer tipo de comprometimento ético/político com tais dilemas dos grupos das artes visuais de Belém, já que esse não seria seu papel, ainda que seus prejuízos colaborativos já se fizessem muito claros se comparados à sua natureza de ativar representatividades locais outrora (Fletcher; Sarraf; Chaves, 2017). Contudo, pelas próprias palavras de Queiroz, a organização, em parceria com o museu, poderia gerar novo fôlego (fôlego para públicos fruidores também) e reiterar uma agenda atualizada de compromissos com a diversidade se trouxesse outros acontecimentos que marcassem o decorrer do salão, inclusive com ocorrências durante os períodos externos à sua agenda anual de realização, com o caso de pré-mostras e de espaços conceituais de trocas, os quais, muito provavelmente, afetariam as vidas de vários e sacudiriam a previsibilidade do Arte Pará.

Muito sensibilizado pela fala de Armando Queiroz, me vi frente à famigerada abertura da mostra, o que por si só me informou acerca do impressionante cronograma previsto para a montagem do salão. Pude olhar com mais calma a narrativa expográfica, agora ciente de todos os imprevistos e provisórias soluções empreendidas nos velozes dias de sua montagem. Também devo mencionar que professores de Arte da universidade, curadores e artistas, ainda criticaram o fato de a exposição parecer muito pequena e sem maior variedade de nomes. Esse ponto ainda parecia a mim muito complexo e inconcluso, haja vista a argumentação procedente tanto do curador acerca de uma qualidade a ser buscada em detrimento de quantidade quanto, por oposição, a argumentação de artistas e de outros atores envolvidos no salão em torno da descaracterização política inclusiva do evento para a comunidade artística local.

Um dado, vale acrescentar, que me surgiu estranho e coincidentemente, naquela noite, foi também relacionado à quantidade vertiginosamente baixa de pessoas na abertura do Arte Pará 2012, se tomarmos por referência os anos anteriores. Os corredores e salões do evento estavam quase que completamente desabitados, e isso em seu dia de culminância. Como bem havia pontuado anteriormente na análise desta presente edição, o evento enfrentava um crescente desafio diante da estruturação de novos hábitos e fruidores, muitos deles criados com novas tecnologias de informação e a partir do privilégio da instantaneidade em detrimento dos tempos locais. Uma vez que a abertura do salão tinha um certo vazio de público, era inegável pensar em uma nova 
significação do Arte Pará frente a diversos instantes de vivências sociais. Esses sintomas permaneceriam nas edições posteriores da exposição?

\section{Uma jornada particular}

Meu segundo ano de pesquisa de campo no processo de montagem do Arte Pará foi um passo natural e já acertado diretamente com a própria Fundação Rômulo Maiorana. Mediante o pedido formal de trabalho, pude estar presente já no primeiro dia das organizações, dia 7 de outubro de 2013.

Quando adentrei no já conhecido local principal da montagem, o Museu Histórico do Estado do Pará, fui recepcionado pelo próprio Paulo Herkenhoff. Foi nesse contexto, portanto, que Paulo me levou para conhecer o espaço destinado ao artista homenageado daquele ano, Alexandre Sequeira (PA), localizado na Sala Manoel Pastana, e apresentou-me a Vânia Leal, curadora educacional do evento e responsável pela assessoria de montagem da supracitada sala.

Vânia foi quem me relatou que o espaço do artista vinha sendo preparado desde a segunda-feira anterior àquele dia e que esse mesmo local já estava em uma etapa de quase conclusão, pois já tinha sido totalmente pintado e estava com a maior parte de suas obras já instaladas. Nesse espaço bem-acabado e estruturado de Sequeira, tomei conhecimento, a partir da própria fala do amigo e artista, que uma grande parte das peças apresentadas eram advindas do período em que estava fazendo mestrado na Universidade Federal de Minas Gerais (UFMG). Essas obras, situadas em um espectro da chamada estética relacional, ${ }^{12}$ firmaram a tônica buscada para escrever sua dissertação: foram erupções poéticas e delicadas, ocorridas durante um período de convivência com um garoto de 13 anos no interior de Minas Gerais, garoto este que tinha ajudado o artista como guia e amigo nessa região. Dessa relação de amizade e parceria, nasceram os diversos elementos também apresentados no Arte Pará e pelos quais poderíamos compor alguma espécie de rede narrativa, capaz de evidenciar a riqueza de suas realidades pareadas, caso, inclusive, de uma armadilha rústica para capturar discos voadores, desejo esse do garoto e garantido pelo artista.

12 A estética relacional pressupõe que o intercâmbio humano é o próprio objeto estético e seu principal elemento caracterizador (Bourriaud, 2009). 
A retomada de minha conversa com Paulo Herkenhoff ainda me trouxe maiores dados para compreender aquela $32^{\mathrm{a}}$ edição. Ela tinha o papel de trazer à tona formas artísticas de se reordenar o mundo, geralmente amparadas pela partilha de vivências e memórias traduzidas em variados suportes, de maneira a aproximar olhares de distintas localidades do país para se criar uma narrativa polifônica para a dimensão estética em Belém (ver também Herkenhoff, 2014). De algum modo aproximável da proposição das artes visuais como abstração da cultura, abstração essa possível de ser experimentada e vivida (Marxen, 2009), o evento em questão reiterou o pressuposto da arte como modo alternativo de comunicação, capaz, em variados casos, de revelar suas engrenagens constituintes como técnicas ativas de etnografia. ${ }^{13}$

Outra operação deveras elucidativa para aprofundar essa noção curatorial do Arte Pará de 2013 pôde por mim ser buscada em Homi Bhabha (2003a), no que concerne à produção de sentidos nas sociedades. Apropriando-se de noções derridianas, na perspectiva do signo em movimento, o autor indiano reivindicou a interpretação das culturas, inclusive as artísticas, como uma estratégia de mobilização dos sentidos, uma vez que todas as suas significações, geradas como efeito da relação ativa e passiva entre presença e ausência, seriam mais bem apreendidas sempre com certo grau de indeterminação, haja vista a impossibilidade de fechamento de uma apreensão cultural por um único relato (Schmidt, 2011).

Distante da noção clássica sobre a condição do signo linguístico definida por Saussurre, Bhabha (2003a) passou a detectar como qualquer rede discursiva se constituiria por um jogo de diferenças em que “[...] o jogo é também um ato de diferenciação, pois compreende diferenças e espaçamentos necessários aos relacionamentos dos signos entre si e sem os quais os significantes não podem significar" (Schmidt, 2011, p. 25) - efeito esse constituinte do Arte Pará, ao buscar algum tipo outro de reordenação do mundo, a partir de microenunciados artísticos em diálogo. $\mathrm{O}$ autor indiano, pertinente para ajudar no entendimento desse contexto curatorial e polifônico do salão, estabeleceu uma crítica para as avaliações puras e simples de significados sociais como sendo as mais ou menos autênticas (e aqui devemos pensar nos territórios não

13 Segundo Eva Marxen (2009), muitas obras de arte tratam de expressar os sentimentos de uma maneira cultural específica, apesar das limitações verbais. 
mapeados e compostos por imagens complexas, as quais fogem das tentativas cada vez mais infrutíferas das nomenclaturas), de forma a reiterar a necessidade de uma significação plurivalente, relacionada a um terceiro lócus contextual de enunciações justapostas, surpreendentes, moventes e deliberadamente contraditórias - característica essa integrante de um olhar fenomenológico próprio à curadoria de Paulo Herkenhoff, contra os fechamentos arbitrários e excludentes das narrativas oficiais (Bhabha, 2003b; Menezes de Souza, 2004).

No que concerne ao andamento de meu trabalho, visitei as salas expositivas com o próprio curador, a fim de observar suas negociações em torno das cores que seriam usadas para pintar tais espaços. E pelo que percebi, os planejamentos prévios de preparação do ambiente expositivo não ocorreram esse ano, de maneira que a agenda de arrumação já se encontrava mais apertada que a de costume - observei que quase todas as principais paredes ainda estavam em estágio de espera ou mesmo manchadas, no aguardo de uma decisão que já deveria ter sido feita com bastante antecipação. ${ }^{14}$

Nesse meio tempo, conheci e conversei com os artistas Federico Herrero, costa-riquenho e premiado internacionalmente, já tendo participado de edições da Bienal de Veneza, e Paulo Sampaio, um senhor já com seus 90 anos, antigo soldado da borracha no período da Segunda Guerra, que fazia uso de suas experiências técnicas e memoriais para construir narrativas de soldado através da arte. Paulo Sampaio, mais especificamente, foi quem contou, para mim, Federico e para Herkenhoff, sobre o processo de feitura de suas tintas através de pigmentos com base no látex vegetal, processo esse capaz de atribuir uma dimensão de significado particular para suas obras. Seus três desenhos ${ }^{15}$ sobre tecido para a exposição, todos pintados com essa tinta de base na borracha, buscaram retratar sua impressionante experiência com a exploração

14 Pelo conhecimento que vim tomar depois, a cor cinza foi a escolhida por Paulo e Roberta para revestir as paredes do MHEP, escolha essa deveras controversa, visto a exposição estar alocada em um prédio histórico já com aquela aparência severa. De qualquer forma, mesmo ante a escolha final da pintura, mais o trabalho direto de uma equipe para a resolução de tal necessidade, o evento daquele ano teria inacreditáveis dois dias para finalizar todo o acabamento do recinto expositivo, para dispor as obras selecionadas e convidadas em seus espaços de apresentação, sem contar com a limpeza necessária para a abertura na noite da quinta-feira.

15 No dia seguinte, Herkenhoff, ainda sensibilizado pela fala de Paulo Sampaio, visitaria o atelier do artista e traria outros desenhos para serem expostos naquela edição do evento. 
dos seringais, a revolta das populações indígenas e os consequentes conflitos envolvendo os exploradores em seu passado.

Na terça-feira, dia 8 de outubro, acompanhei o processo de pintura e intervenção de Federico Herrero no espaço interno do pátio do próprio Museu Histórico do Estado do Pará. Conforme Federico me relatou, seu maior desejo seria o de achar um muro na cidade para receber uma pintura sua com tinta acrílica. Todavia, frente à dificuldade e falta de equipamento para mapear algum sítio apropriado - o MHEP encontra-se na Cidade Velha, área tombada como patrimônio histórico pelo Instituto do Patrimônio Histórico e Artístico Nacional (Iphan) -, o artista optou por fazer somente aquela intervenção, já que mesmo a fundação e o museu não haviam lhe mostrado maior interesse para facilitar uma ação sua de maior envergadura em alguma área externa.

Ao fim daquela terça-feira, observei que o processo de montagem havia tomado novo fôlego e pareceu ganhar um ritmo mais acelerado. $\mathrm{O}$ único problema, até aquele presente instante, mostrou ser ainda a pintura das paredes das salas expositivas, pois essas continuavam manchadas, mesmo após uma segunda demão - e aqui convergiu uma problemática: por conta da espessura e da umidade das paredes antigas do museu, havia um impedimento físico para que mais demãos fossem passadas até alcançar a estabilidade necessária/ mínima.

Na quarta-feira, dia 9 de outubro, outro evento se tornou marcante: junto do artista convidado Pablo Lobato (MG), que havia chegado a Belém para apresentar sua obra Bronze revirado, Herkenhoff me propôs uma momentânea parceria, que teria, além de Pablo e eu, a artista selecionada Marina Boaventura (TO). Paulo, conforme nos explicou, colocaria a mim para ser uma espécie de guia para a performance que Marina reapresentaria no vernissage na quinta-feira, de maneira que eu participaria como um orientador para a passagem da artista pelas dependências do enorme prédio. ${ }^{16}$ Esse meu papel, mais especificamente, seria somente de estar atento ao vídeo de Pablo, que seria apresentado no pátio interno do museu, a fim de que manifestasse seus picos sonoros em sintonia

16 A obra de Marina Boaventura compõe não somente o ato performático, como também o vestido usado por ela, costurado, pintado e bordado durante dois anos em que esteve se recuperando de situações de assédio moral e de machismo no trabalho (Maiorana et al., 2014). 
com a passagem da artista por alguns recintos do espaço para, assim, trazer algum tipo de dramaticidade para a abertura.

Na quinta-feira, dia 10 de outubro, fui até o Museu Paraense Emílio Goeldi para prestigiar a abertura daquela mostra do salão. Como todo evento daquela natureza, ocorreu uma apresentação cerimonial, com as falas da curadora educacional Vânia Leal, do curador Paulo Herkenhoff, dentre outros ligados a esse museu. Herkenhoff, mais especificamente, pontuou em que medida o Arte Pará, para ele, poderia ser visto como um espetáculo da educação, diferente do dito por Guy Debord (espetáculo como mercadoria e alienação). Em seu discurso, também falou sobre a maior ação educativa de um salão de arte do país, com seus cem mil exemplares de informativos educativos, e sobre como o evento estava em uma trama intercultural crescente, muito em virtude de trazer artistas convidados de fora para prover convivências e trocas artísticas.

Após o coquetel daquele evento, voltei ao MHEP, quando pude acertar outros detalhes com os responsáveis pela iluminação do espaço para a performance da artista Marina Boaventura. Acertados esses pormenores, constatei somente que o problema das paredes manchadas se mostrou instransponível, de maneira que algumas das salas expositivas ficaram profundamente incômodas e comprovaram que a montagem do salão transcorreu em uma agenda deveras reduzida e não aconselhável. Por volta de 16h daquela quinta-feira, os jurados ${ }^{17}$ chegaram para votar nos vencedores alocados em seus espaços de apresentação, sendo que alguns artistas foram visivelmente prejudicados, em minha opinião, pelo estado quase deplorável das suas paredes, paredes essas capazes de afetar qualquer tipo de fruição mais neutra.

Pelo início da noite, acompanhei o cerimonial de abertura oficial e tomei conhecimento dos grandes ganhadores daquela edição de 2013: o grupo de Bia Medeiros, Corpos Informáticos (DF), Grande Prêmio com a performance orientada para o vídeo Mas afinal, o que será que se passa na alma do artista? (Arte..., 2013). Além desse momento, envolvi-me com a apresentação performática de Marina Boaventura, que saiu de acordo com o planejado, de maneira a criar um ambiente lírico à abertura (Figura 3).

17 Nessa edição, o júri de seleção foi composto por Janaína Melo, Cristina Tejo, Paulo Herkenhoff, Marisa Mokarzel e Walda Marques, e o júri de premiação por Marisa Mokarzel, Paulo Herkenhoff e Walda Marques. 


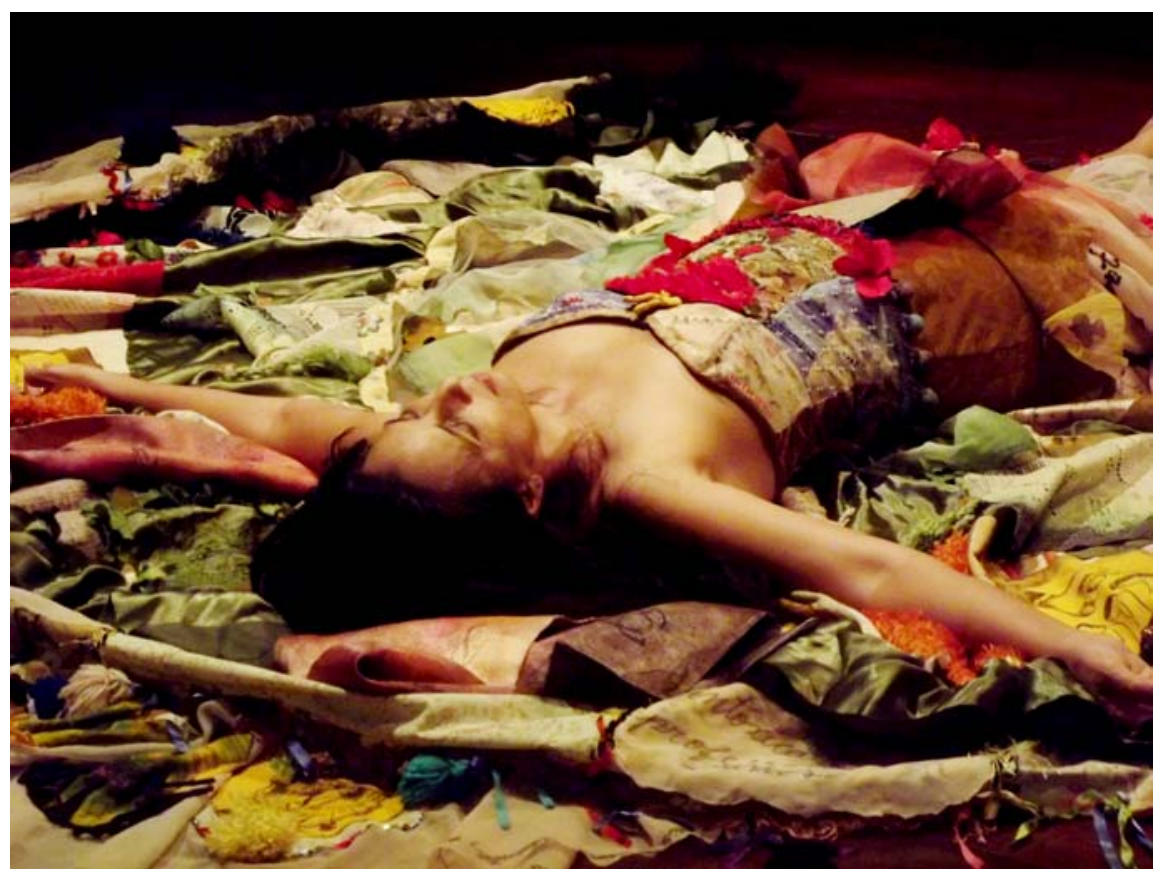

Figura 3. Artista Marina Boaventura no encerramento de sua performance, Assédio moral, durante a abertura do Arte Pará 2013 (foto do autor).

Outro ponto destacável para aquela noite de abertura ocorreu com alguns alunos da Faculdade de Artes Visuais e seus recorrentes manifestos por não ganharem possibilidade equitativa de participação no Arte Pará. Semelhante ao que havia visto no ano anterior, quando alunos carregavam cartazes com os escritos “Arte para quem?", vestiam máscaras ou roupas não convencionais para declarar um tom de deboche; suas ações, naquele 2013, também envolveram performances satíricas - alguns fingiam incorporações, gritando e se debatendo nos chãos do museu, ao passo que outros, carregando restos de fezes, recebiam os visitantes do salão na sua porta de entrada. Tomo todas as manifestações por necessárias, feitas para reivindicar por mais espaço estudantil e atenção durante o cerimonial de abertura.

Percebi, não obstante, que muitos artistas e visitantes ficaram insatisfeitos com essas ações impetradas pelos alunos. Todavia, e isso é uma opinião minha, tais intervenções foram significativas para mostrar outra camada de um evento 
que se tornou refém de seus critérios limitantes. Uma vez que o salão não havia buscado nem mesmo uma mostra paralela e universitária para exercer outro tipo de abrangência, considerando o aumento de programas de graduação em Artes Visuais na cidade, sua dificuldade de criar distintas conexões com o novo mapa visual que vinha se formando em Belém nos últimos anos somente pareceu se fortalecer. A sua dificuldade de estranhar e de enfrentar a estruturação de novos hábitos e fruidores, muitos deles tensionados por novas tecnologias de informação e contestação, era inquestionável.

\section{Cultura e natureza}

Os trabalhos de observação da $33^{a}$ edição do salão começaram na segunda feira, dia 6 de outubro de 2014, após receber a confirmação de entrada para o processo de montagem. Direcionei-me, desse modo, ao Museu Histórico do Estado do Pará para desenvolver a terceira etapa de minha pesquisa.

Logo ao chegar, fui recebido por Paulo Herkenhoff, novamente curador geral, Armando Queiroz, curador assistente para as salas do Espaço Cultural Casa das Onze Janelas, e por Roberta Maiorana, diretora executiva da Fundação Rômulo Maiorana. Foi com Herkenhoff que me detive primeiramente, e ele me falou sobre a mostra Amazônia: Ciclos da Modernidade, que faria parte da programação daquele Arte Pará. Explicou-me, desse modo, que, do capital total obtido para a sua concretização, somente um quarto desse valor foi voltado para atender as suas versões menores apresentadas em Belém e em Manaus (sendo a de Belém a organizada junto ao Arte Pará). Uma vez que o projeto principal da exposição foi pensado para o Rio de Janeiro, no Centro Cultural Banco do Brasil (CCBB-Rio), com o uso de três quartos da verba total para sua montagem, as etapas nessas duas capitais brasileiras seriam desdobramentos menores da primeira, previstas pelo próprio curador, ainda que trouxessem um elenco quase inteiro de artistas do Norte do país.

A referida mostra, conforme Herkenhoff delineou, tratou de ocupar o segundo andar do MHEP, fazendo uso de algumas das salas frontais desse edifício - algo pouco explorado nesses últimos anos -, ao passo que o corpo de selecionados e de convidados para o salão regular, por outro lado, além de permanecer no primeiro andar do museu, também pôde ocupar o Espaço Cultural Casa das Onze 
Janelas: Sala Valdir Sarubbi, com o convidado especial Guy Veloso em diálogo com o fotógrafo Pierre Verger; e o Laboratório das Artes dessa mesma instituição, com a amiga e parceira de Guy em pesquisas de campo em terreiros de umbanda e candomblé, Edivânia Câmara. Edivânia, vale acrescentar, ficou responsável por montar, no supracitado espaço, uma mostra de indumentárias cerimoniais do candomblé (Oxum, Yemanjá, Nanã e de uma Padilha), a fim de costurar outra nuance para o diálogo em torno de religiosidades estabelecido por Veloso e Verger. O Arte Pará 2014, não obstante, também teria uma mostra do artista homenageado Paulo Sampaio no Museu Paraense Emílio Goeldi, com curadoria assistente assinada por Margalho Açú. Paulo Sampaio, um generoso senhor com seus mais de 90 anos, cujas experiências como soldado durante o período da borracha foram transpostas para o universo da pintura, havia falecido naquele ano em questão, matizando simbolicamente aquela própria edição do evento com um tom de luto.

Como já era de costume nas últimas edições do salão, a sua proposição temática ficou aberta, porém com certa tendência para abordar as relações entre o corpo e a natureza. Conforme destacado por Armando Queiroz (2015) para o texto de apresentação do catálogo da exposição, aquela presente edição se ofereceria como oportunidade para se problematizar os diversos modos de estar no mundo, estados esses significativos e contraditórios para se instigar as consciências e as contingências do corpo.

Sob um ponto de vista antropológico, o Arte Pará 2014 não se mostrou tão distante do que foi por muitos apontado como um momento de redescoberta da natureza como uma aliada na luta contra as sociedades exploradoras, em que a violação da natureza agrava a violação do homem (ver Leff, 2013). Uma vez que as múltiplas visões sobre o duplo cultura-natureza se posicionaram a analisar tanto os contextos de conhecimento e de poder ${ }^{18}$ quanto as alternativas empíricas e teóricas sobre o entendimento prático do ambiente (ver Descola; Pálsson, 2001; Santamarina Campos, 2008; Silveira, 2009), aquela montagem, por apresentar obras com diversos elementos simétricos em relação à ecologia política, reiterou formas de valorizar modos de vida mais tradicionais e abriu

18 Os conflitos derivados da distribuição desigual e das estratégias de apropriação dos recursos ecológicos, dos bens naturais e dos serviços ambientas, com eventual hierarquização desfavorável dos sujeitos e modos de vida de populações tradicionais vieram nesta dinâmica expográfica do Arte Pará (ver também Leff, 2003; Escobar, 2010). 
possibilidades outras para uma consciência ecológica via discursos visuais alocados entre o caráter incontrolável da natureza e um posicionamento crítico quanto aos efeitos predatórios e entrópicos do homem como seu participante e maior algoz (Ulloa, 2009) - possibilidades essas muito visíveis nas obras de Luciana Magno (PA), Pedra do Sol e Trans Amazônica. ${ }^{19}$

Na terça-feira, dia 7 de outubro, pude conversar longamente com Roberta Maiorana, que tratou de me explicar o novo projeto de cores para o MHEP. Ainda nesse contexto, soube que o Salão andava com um custo médio de R\$300.000,00, algo muito abaixo do que imaginava, sendo que, desse valor, $60 \%$ eram voltados para o evento em si, e $40 \%$ para o gerenciamento da fundação. Vale acrescentar, não obstante, que aquele ano trouxe um orçamento deveras restrito, muito em virtude da falta de maior apoio de seus costumeiros investidores por conta das campanhas políticas (estávamos em um ano de eleições presidenciais).

Ao final do dia, por outro lado, observei que a artista Juliana Notari (PE) foi quem teve de enfrentar problemas técnicos dessa vez. Ela estava junto da artista Luciana Magno, e ambas me explicaram suas dificuldades com seus vídeos, que estavam em extensão mov. Uma vez que ainda não havia qualquer suporte técnico, trataram de solucionar elas mesmas, da melhor maneira possível, a transcodificação dos arquivos, visivelmente chateadas com essa falta de recursos humanos específicos. A companhia das duas também me trouxe outro tipo de esclarecimento sobre aquele Arte Pará, principalmente por conta de seu reduzido número de selecionados: sua configuração veio com 20 artistas, diferentemente do ano anterior, com 25 , ao passo que, em outras edições, já tivéramos números superiores a cem. Nesse sentido, ficava cada vez mais questionável a argumentação curatorial para se obter uma exposição dita mais concisa e de melhor qualidade. Seria esse realmente o motivo para o encolhimento do evento? Para complicar esse cenário do salão, as duas ainda me informaram acerca da diminuição da ajuda de custo para quem fosse selecionado, uma vez que os valores caíram dos simbólicos $\mathrm{R} \$ 1.500,00$ para $\mathrm{R} \$ 1.000,00$. Ficava claro que as prioridades para enxugar o orçamento prejudicaram principalmente os artistas participantes e reais componentes para gerar qualquer interesse pela mostra.

19 Uma interpretação antropológica desta obra pode ser conferida em Fletcher e Albán (2015). 
Na quarta-feira, dia 8 de outubro, encontrei-me com Armando Queiroz e Edivânia Câmara nas dependências da Casa das Onze Janelas. Extremamente gentis, os dois me convidaram para acompanhá-los em uma série de buscas de materiais para a abertura da exposição em outros pontos da cidade. Fomos, desse modo, à Escola de Teatro e Dança da UFPA para pegar três manequins, que tinham sido confeccionados, em papel machê, para vestir as indumentárias cerimoniais da sala de Edivânia. Em seguida, direcionamo-nos ao bairro da Sacramenta para visitar um senhor chamado Robson, que cederia indumentárias indígenas cerimoniais para compor a mesma mostra. Como o Sr. Robson não estava em sua casa, fomos recebidos por outro senhor, de nome Carlos, historiador e colecionador tradicional de arte indígena.

Da casa do Sr. Robson ainda fomos à casa do Sr. Carlos para conhecer duas mulheres da etnia Mebêngôkre-Kayapó, que estavam lá hospedadas. Por volta do início da tarde, quando retornamos ao carro para voltar à montagem do salão, vim tomar conhecimento de como Armando teve contato com o Sr. Robson e se envolveu ainda mais com os problemas enfrentados pelas comunidades tradicionais mais aproximadas do contexto belenense: em 2008, participou da organização de uma exposição para a Semana dos Povos Indígenas. Em face ao sucesso da mesma, assumiu a responsabilidade de dar continuidade ao evento em 2009, já em uma dimensão maior, momento em que conheceu o Sr. Robson. A amizade entre Armando e o Sr. Robson se fortaleceu no decurso daquele tempo e gerou uma série de novas parcerias em torno dessas emergências.

Em nosso retorno, vale acrescentar, Edivânia percebeu que as indumentárias trazidas não estavam com energias convergentes para ficar na mesma sala que as dos orixás. Havia, nesse caso, um conflito energético desestabilizador, principalmente pela presença da indumentária da Padilha. E como Edivânia possuía mediunidade, seu trabalho de arrumação da sala estava passando por uma resistência forte advinda desse conflito de outras ordens. Algum tempo depois, a própria Edivânia decidiu que não seria adequado misturar as indumentárias indígenas com as do candomblé, de maneira que deixou, na sala de Armando, ${ }^{20}$ as que tínhamos trazido da coleção de Sr. Carlos - e com a retirada das indumentárias em questão, me disse que seu trabalho para terminar a organização

20 É válido destacar que nesse período da exposição, Armando Queiroz exercia a função de diretor do Espaço Cultural Casa das Onze Janelas. 
do Laboratório das Artes tinha ficado muito mais ameno e promissor. Tomo esse como um interessante ponto para se pensar a complexa montagem do salão.

Na quinta-feira, dia 9 de outubro, iniciei minhas atividades no MHEP, pois haveria uma conversa entre mediadores e artistas, ao passo que, no Museu Paraense Emílio Goeldi ocorreria a abertura da mostra do artista homenageado Paulo Sampaio, falecido no começo do ano - eu, particularmente, não me sentia à vontade para participar de sua abertura naquele momento, ainda mais diante da memória recente e dolorosa de sua partida. Uma vez que o bate-papo, no MHEP, ocorreu sem maiores novidades - com os artistas Edu Simões (SP), Rodrigo Arruda e Andrea Barreiro (SP) -, tratei somente de observar o diálogo com os mediadores, os quais, todos muito jovens e nervosos, demonstraram pouca segurança com as artes visuais recentes, incorrendo, às vezes, em perguntas quase retóricas.

O início da tarde foi igualmente típico, ao passo que, com a chegada de Paulo Herkenhoff, Roberta Maiorana, Éder Chiodetto e Armando Queiroz, iniciaram-se as análises finais para a premiação ${ }^{21}$ das obras selecionadas: Paul Setúbal (GO), recebeu o Prêmio para Pintura; Luciana Magno e Juliana Notari, foram, cada uma, premiadas por suas performances orientadas para o vídeo; e Costa \& Brito (SP), também foram com uma série de três ações voltadas para o vídeo, extremamente simples e inteligentes para se atribuir um olhar estético a experimentações de equilíbrio com os corpos dos artistas junto de materiais encontrados nas ruas.

No que concerne à abertura do salão propriamente dita, já no início da noite, participei de uma primeira, fechada para empresários e artistas, antes da abertura oficial. Essa cerimônia, voltada para dar mais atenção aos patrocinadores, foi uma estratégia para a fundação evitar um formalismo exagerado aos que viriam para a posterior, como público geral, sem contar que visou a uma precaução, caso ocorressem manifestações de alunos de artes visuais da Universidade Federal do Pará - fato esse não ocorrido. De qualquer forma, tal abertura também possibilitou, dentro de sua cerimônia habitual, uma visita guiada com o próprio curador, Paulo Herkenhoff e com Éder Chiodetto.

21 O júri de seleção desse Arte Pará foi composto por Paulo Herkenhoff, Éder Chiodetto, Armando Queiroz e por meu orientador, Ernani Chaves, ao passo que o júri de premiação foi composto Paulo Herkenhoff, Éder Chiodetto e por Armando Queiroz. 
O término do meu trabalho de pesquisa para esse recorte de 2014, vale acrescentar, encerrou-se sem a exuberância de quando o trânsito de artistas era maior, o que possibilitava um espaço de diálogos muito mais proveitoso em torno de produções artísticas e de relações humanas. Uma vez que o decréscimo, seguindo os três últimos anos, em termos de números de selecionados continuava a se mostrar visível, sobrava para cada visitante ou artista a sensação de que mais do que uma crise a se instalar, crise essa embebida por negociações, contradições e avanços, o modelo já tão tradicional e participante do calendário artístico anual paraense avisava, em alto e bom som, que o salão estava no curso de modificações arriscadas frente à perda do restante de sua importância/representatividade de outrora.

Belém, nesse contexto, tinha ganhado muito mais espaço com as artes visuais no país, isso em grande medida fortalecido pelos anos significativos e agregadores proporcionados também pelo Arte Pará. Observar a transformação da atenção pública ao evento ${ }^{22}$ demonstrava não somente que uma parcela da produção paraense encontrou mais autonomia e novas formas, inclusive independentes, de inserção/diálogo no circuito das artes local, nacional e estrangeiro, como também atores e obras participantes de modos menos formais se emanciparam e dessacralizaram o território simbólico de conforto que o salão julgava ter.

\section{O começo é o fim é o começo}

Conforme já mencionado, meu trabalho etnográfico se prolongou até o ano de 2015. Todavia, essa edição em questão, última para o desenvolvimento de minha tese, surpreendentemente traçou uma reconfiguração profunda - reconfiguração essa na qual inscrições para artistas selecionados foram extintas, legando ao novo Arte Pará uma narrativa expográfica feita somente com artistas convidados.

22 Devo aqui acrescentar que o decréscimo de atenção ao evento não tem ocorrido somente em sua noite de abertura, pois tomo como significativo um grande número de relatos de artistas, produtores culturais e curadores que continuamente me informam seu baixo interesse também em visitar o Arte Pará nos seus meses de ocorrência. 
Com a sua $34^{\mathrm{a}}$ edição, o Arte Pará estabeleceu um divisor de águas para seu próprio processo interno de produção de uma história da arte, não mais somente paraense. A tônica que passou a alicerçar os argumentos para a saída da mostra competitiva, em prol de uma mostra unicamente de artistas convidados, limitada e limitante a artistas e localidades com pouca inserção em circuitos de artes visuais e espaços museais mais formais, tratou de revelar que 0 evento estava sim à procura de experimentar suas engrenagens, suas verdades e de se colocar em xeque. Todavia, carecia, nesse constante processo de avanços e retrocessos, refletir profundamente acerca de seu papel, de sua missão e de seu contexto, componentes esses significativos para, ainda, manter seu prestígio para a cena artística de Belém.

Na segunda-feira, dia 5 de outubro, no Museu Histórico do Estado do Pará, Paulo Herkenhoff me fez tomar ciência de que o número de artistas seria ainda menor, mesmo somente com convidados, totalizando um enxuto conjunto de 17 artistas/grupos. Esse conjunto de 17 projetos foi obtido por meio de um diálogo ${ }^{23}$ do curador com outros três curadores adjuntos: Armando Queiroz (regiões Norte e Centro-Oeste), Pablo Lafuente (Sul e Sudeste) e Bitu Cassundé (Nordeste). Os supracitados curadores adjuntos montaram/coordenaram os pequenos elencos que lhes foram pedidos, baseados em nomes da produção nacional e de acordo com suas redes de contatos, para, então, junto do curador geral, chegarem ao número final para compor a mostra da edição de 2015.

Tratei, não obstante, de me aproximar de artistas que lá estavam no MHEP para, então, compreender qual seria a proposta conceitual daquela edição: ênfase em Wagner Barja (DF), artista e coordenador do Museu da República; Lucas Gouvêa e Wellington Romário (PA), antigos alunos da Faculdade de Artes Visuais/UFPA e grandes críticos durante as aberturas do salão em anos anteriores ${ }^{24}$ e Daniel Lie (PE), Fabiana Faleiros (RS), Bárbara Wagner (DF) e Benjamin de Búrca (Munique, Alemanha), artistas também selecionados para compor a mostra do supracitado equipamento cultural. Por meio desses diálogos

23 Devo acrescentar, a título de informação, que essa seleção de artistas ocorreu em julho daquele mesmo ano, no Rio de Janeiro, visto que Paulo Herkenhoff ainda ocupava o cargo de diretor artístico do Museu de Arte do Rio (MAR).

24 A entrada dos mencionados artistas, componentes do qUALQUER qUOLETIVO, tinha ocorrido pela seleção pessoal do curador espanhol Pablo Lafuente, quando de sua aproximação com os mesmos durante a 31 ${ }^{\mathrm{a}}$ Bienal de São Paulo, em 2014. 
com alguns dos convidados, percebi que aquele ano de 2015 trataria de integrar diferentes linguagens artísticas, com uma certa inclinação para o complexo e multifacetado campo da performance. ${ }^{25}$

Outro dado que me foi apreensível, com sua não solução até a abertura do salão na noite do dia 8 de outubro, foi o atraso da equipe de montagem, mais uma vez, para pintar as salas expositivas (com o reincidente caso de greve dos Correios, o que fez com que as fotografias e objetos de Barja, dessa vez, também se encontrassem presos em trânsito). A questão das pinturas atrasadas e, literalmente, de mau acabamento para um evento daquela envergadura seguiram os mesmos argumentos de anos anteriores: a disposição de pouco tempo útil fornecido pela diretoria do museu. Frente à reincidência desses contratempos, somente percebi um quase fatalismo resignado por parte dos organizadores para que a abertura ocorresse de maneira, digamos, dentro da agenda prevista.

De terça-feira a quinta-feira, o processo de montagem seguiu um ritmo muito mais desacelerado, com destaque, mais especificamente, para as dificuldades que os artistas Luiz Braga (PA), Bárbara Wagner e Benjamin de Búrca tiveram com a qualidade insatisfatória dos equipamentos de projeção dos seus respectivos vídeos. Braga, por sinal, foi muito gentil em não demonstrar maior descontentamento quando da não presença de algum técnico de TI que pudesse entender o melhor funcionamento de um equipamento de data show, mesmo que seu vídeo, sem título, tivesse ficado, literalmente, prejudicado durante o vernissage. Ao passo que Bárbara Wagner e Benjamin de Búrca tiveram uma reação de maior inconformidade. Contestaram e, como era de direito deles, tiveram a troca do equipamento de projeção e do anteparo de apresentação do vídeo após uma série de discussões de portas fechadas com o curador Herkenhoff e com Roberta Maiorana - o equipamento anterior era de baixa resolução, da mesma forma que as paredes manchadas interferiam substancialmente na recepção da projeção integrante da instalação Faz que vai, um entrecruzamento de quatro personagens dançando variados ritmos coreográficos, de maneira a tocar questões relacionadas aos corpos, gêneros e suas performances.

25 Para maiores dados sobre algumas das experiências conceituais da performance, ver Fletcher e Chaves (2015). 
A abertura da edição de 2015, por outro lado, foi muito significativa para meu trabalho sobre o Arte Pará e sobre aquela última edição a ocupar o MHEP 26 (as exibições de 2016 e de 2017 se concentrariam somente no Espaço Cultural Museu Casa das Onze Janelas, sendo ele menor espacialmente). Logo de entrada, pude conversar com os artistas Wellington Romário (já imerso em sua persona Bycha do Mato, uma presença e um trocadilho cínico e, de certa forma, drag para problematizar os corpos amazônicos) e Lucas Gouvêa, ambos vestidos para satirizar a Fundação Rômulo Maiorana e o Salão Arte Pará (Figura 4). Junto dos demais visitantes, um público de não mais de 60 pessoas no total, eles deram uma tônica distinta para o evento, cujos últimos anos tinham transcorrido em um já característico formalismo, com suas roupas sociais e comentários feitos em voz baixa.

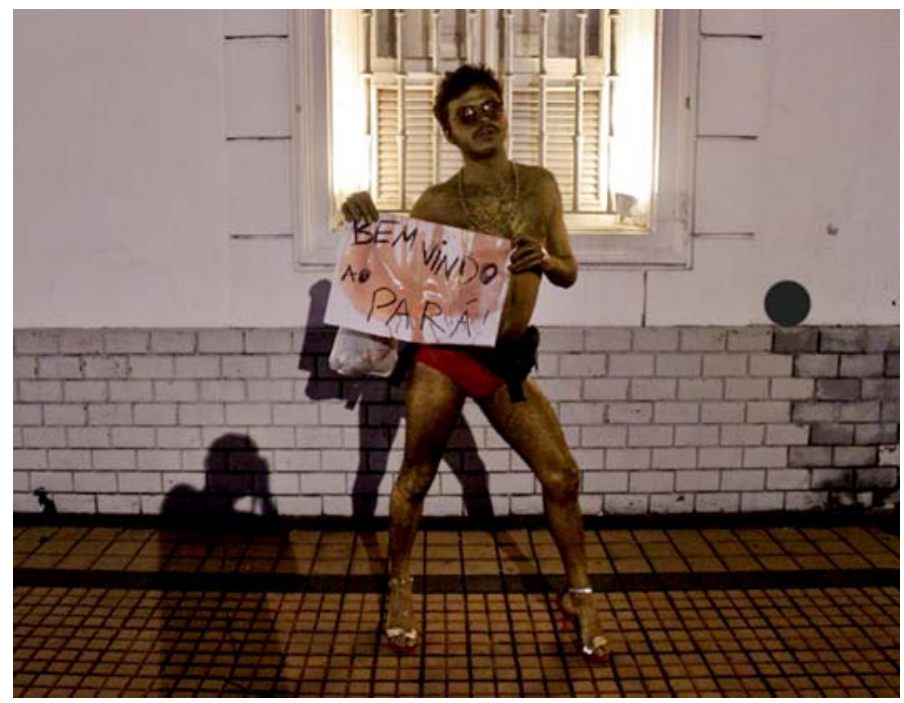

Figura 4. Wellington Romário (Bycha do Mato), na entrada do MHEP, durante a abertura do Arte Pará 2015 (foto do autor)

26 Além do MHEP, o ano de 2015 incluiu o próprio Espaço Cultural Museu Casa das Onze Janelas, com destaque para obras de Virgínia de Medeiros (BA), Elza Lima (PA) e do qUALQUER qOLETIVO, de Wellington Romário e Lucas Gouvêa; e o Museu Paraense Emílio Goeldi, prédio da Rocinha, com destaque para obras de Romy Pocztaruk (RS) e de Yuri Firmeza (SP). 
Também notei um certo desconforto entre os organizadores por conta daquela nova geração de artistas presentes no salão. Uma vez que outras agendas representativas do século XXI tinham atravessado o corpo do Arte Pará a partir de suas estruturas internas, não mais de maneira exógena a ele por meio de manifestações, penso eu que choques geracionais e de pensamento se fizeram evidentes aos poucos presentes como nunca antes. De todo modo, contrário à recepção de alguns lá, tive uma das mais leves e agradáveis aberturas, uma vez que vi, em seu interior, uma deixa para perguntas substanciais acerca dos limites de nossas sociedades irregulares e atravessadas por ordens de pensamento hierarquizantes.

Nesse sentido, retomo com grande entusiasmo Fabiana Faleiros, que fez o seu pocket show sobre feminilidade, descobrimento do corpo pela masturbação e liberdade em uma área conhecida por cela, antigo local de confinamento do prédio histórico, utilizado durante os séculos XIX e início do XX. Ao passo que Daniel Lie ocupou a área do pátio interno do museu imerso em uma performance xamânica com house music orientada para uma instalação, na qual depositava, em três grandes sacos de plástico presos no corredor do prédio, restos de alimentos e frutos locais para apodrecerem no decurso da exposição até seu encerramento em dezembro (uma interlocução com a paisagem e com a cultura de Belém, e daí tirar uma reflexão visual sobre a inevitabilidade). Novas gerações e novos pensamentos e estratégias para se potencializar o espectro reflexivo e lúdico das artes visuais.

\section{Algumas considerações}

No decurso desses anos de acompanhamento sincrônico das montagens do Arte Pará, tomei maior conhecimento em torno das contradições alocadas no seu organismo próprio, bem como testemunhei um regime de historicidade artístico que se transformou e perdeu, para muitos, sua maior força constituinte: algumas das relações de sociabilidade e afeto a partir das artes visuais no e para um contexto regional específico.

Em cada um desses anos (2012-2015), o decréscimo de artistas selecionados e/ou convidados para participar, decréscimo esse também atravessado por uma equipe de apoio pequena ou inexistente - vide o caso da ausência, em 
pleno século XXI, de uma equipe de TI ou de maiores estratégias profissionais de inserção do evento em mídias sociais -, ajudou a transformar/reordenar um ambiente local propício para o contato, a troca, a pesquisa e a inspiração entre artistas, pesquisadores, curadores e fruidores, com uma inevitável dispersão de algumas das energias específicas que fizeram, um dia, do evento uma referência para a cidade de Belém.

O Arte Pará, articulado dentro de um contexto privado em toda sua trajetória, bem deve ser continuamente entendido à luz de um enredo geo-histórico e assimétrico, com distintas forças e negociações. Ainda que seja do conhecimento de que a transformação é a face inalienável de inúmeros eventos artísticos e equipamentos culturais, sua intermitência para com uma luta simbólica, a qual, em linhas gerais, deveria manter-se contínua, descentralizada, autoquestionadora, autocrítica e solidária em torno de uma região e de uma população historicamente colocadas nas periferias de um mundo intercultural, insinuou uma noção de mundo conectado, porém de acordo com convergências pontuais, mas não necessariamente integrais.

Os anos que se seguiriam veriam um país mergulhado em extremismos sombrios, com a perda gradativa de espaços e de respeito para com discursos em torno de sociedades plurais, com a consequente desvalorização de populações brasileiras, quer sejam jovens, indígenas, negras, tradicionais, femininas e/ ou LGBTQ. A reiteração de um posicionamento mais claro quanto ao convívio com base no pensamento progressista e respeitoso se mostraria como uma possível faceta a ser recuperada pelo salão. Entendê-lo e praticá-lo como território de direito à fala, à diferença, à democracia, em oposição à existência de vultos sombrios no discurso e na política cultural brasileira, muitos desses aliados à existência da censura, do apagamento, do desrespeito e do extermínio de quem pensa diferente, seria uma pertinente via, rumo às atualidades e contradições dos novos tempos. 


\section{Referências}

ALBÁN, A. Estéticas decoloniales y de re-existencia: entre memorias y cosmovisiones. In: HAIDAR ESPERIDIAO, J.; SÁNCHEZ GUEVARA, S. (coord.). La arquitectura del sentido II: la producción y reproducción en las prácticas semiótico-discursivas. Ciudad de México: Escuela Nacional de Antropología y Historia/Instituto Nacional de Antropología y Historia, 2011. p. 87-117.

ALVIM, P. A.; BRANCO, L. A. G.; ROCHA, P. L. B. V. Os salões de arte e o surgimento da cultura de massa nos séculos XVIII e XIX. In: Encontro da Associação Nacional de Pesquisadores em Artes Plásticas, 16., 2007, Florianópolis. Anais [...] Florianópolis: Associação Nacional de Pesquisadores em Artes Plásticas, 2007. v. 1, p. 484-495.

ARTE Pará 2013. O Liberal, Belém, 13 out. 2013. Caderno Liberalzinho, p. 1-16.

BHABHA, H. K. Como o novo entra no mundo: o espaço pós-moderno, os tempos pós-coloniais e as provações da tradução cultural. In: BHABHA, H. K. O local da cultura. Belo Horizonte: Ed. UFMG, 2003a. p. 292-325.

BHABHA, H. K. O pós-colonial e o pós-moderno: a questão da agência. In: BHABHA, H. K. O local da cultura. Belo Horizonte: Ed. UFMG, 2003b. p. 239-273.

BOURRIAUD, N. Estética relacional. São Paulo: Martins Fontes, 2009.

CLIFFORD, J. Sobre a autoridade etnográfica. In: GONÇALVES, J. R. S. (org.). A experiência etnográfica: antropologia e literatura no século XX. Rio de Janeiro: Ed. UFRJ, 1998. p. 17-62.

CRAPANZANO, V. Diálogo. Anuário Antropológico/88, Brasília, p. 59-80, 1991.

DESCOLA, P.; PÀLSSON, G. Introducción. In: DESCOLA, P.; PÀLSSON, G. (coord.). Naturaleza y sociedad. Ciudad de México: Siglo XXI, 2001. p. 1-33.

DIDI-HUBERMAN, G. Quando as imagens tocam o real. Pós: Revista de Pós-Graduação em Artes da Escola de Belas Artes da UFMG, v. 2, n. 4, p. 206-219, 2012.

ESCOBAR, A. Epistemologías de la naturaleza y colonialidad de la naturaleza: variedades de realismo y constructivismo. In: ESCOBAR, A. Territorios de diferencia: lugar, movimientos, vida, redes. Popayán: Envión, 2010. p. 141-152.

FABIAN, J. The other revisited. Anthropological Theory, v. 6, n. 2, p. 139-152, 2006.

FLETCHER, J.; ALBÁN, A. Interpretações visuais nos territórios da ecologia política: aproximações e distanciamentos entre a Amazônia oriental e a ocidental. Cadernos de Campo, n. 24, p. 71-89, 2015. 
FLETCHER, J.; CHAVES, E. Gallus sapiens: um projeto artístico, de Victor de la Rocque, sob um olhar antropológico. Cadernos de Arte e Antropologia, Salvador, v. 4, n. 2, p. 71-87, 2015.

FLETCHER, J.; SARRAF, A.; CHAVES, E. Visualidades amazônicas e interculturais nos primeiros anos do Arte Pará. Ilha: Revista de Antropologia, Florianópolis, v. 19, n. 1, p. 71-102, 2017.

GEERTZ, C. Estar aqui: de quem é a vida, afinal?. In: GEERTZ, C. Obras e vidas: o antropólogo como autor. Rio de Janeiro: Ed. UFRJ, 2009. p. 169-193.

GELL, A. Art and agency: an anthropological theory. Oxford: Claredon, 1998.

HERKENHOFF, P. Percursos no Arte Pará. In: MAIORANA, R. et al. Arte Pará 2012. Belém: Fundação Rômulo Maiorana, 2013. p. 6-7.

HERKENHOFF, P. Percursos no Arte Pará. In: MAIORANA, R. et al. Arte Pará 2013: ano 32. Belém: Fundação Rômulo Maiorana, 2014. p. 6-7.

JULIÃO, L. Apontamentos sobre a história do museu. In: CADERNO DE DIRETRIZES MUSEOLÓGICAS. Brasília: Ministério da Cultura; Belo Horizonte: Secretaria de Estado da Cultura, 2006. p. 17-30.

LEFF, E. La ecología política en América Latina: un campo en construcción. Sociedade e Estado, v. 18, n. 1, p. 17-40, 2003.

LEFF, E. Ecologia política: uma perspectiva latino-americana. Desenvolvimento e Meio Ambiente, v. 17, p. 11-20, 2013.

LOURENÇO, M. C. F. Museus acolhem moderno. São Paulo: Edusp, 1999.

LUZ, A. A. Salões oficiais de arte no Brasil: um tema em questão. Arte e Ensaios, n. 13, p. 58-63, 2006.

MAIORANA, R. et al. Arte Pará 2012. Belém: Fundação Rômulo Maiorana, 2013.

MAIORANA, R. et al. Arte Pará 2013: ano 32. Belém: Fundação Rômulo Maiorana, 2014. MANTECÓN, A. R. Globalización cultural y antropología. Alteridades, v.3, n. 5, p. 79-91, 1993. MARXEN, E. La etnografía desde el arte: definiciones, bases teóricas y nuevos escenarios. Alteridades, v. 19, n. 37, p. 7-22, 2009.

MENEZES DE SOUZA, L. M. T. Hibridismo e tradução cultural em Bhabha. In: ABDALA JUNIOR, B. (org.). Margens da cultura: mestiçagem, hibridismo e outras misturas. São Paulo: Boitempo, 2004. p. 113-133.

MIGNOLO, W. Histórias locais/projetos globais: colonialidade, saberes subalterno e pensamento liminar. Belo Horizonte: Ed. UFMG, 2003. 
MOREIRA, G. P. G. Veredas e construções de uma política nacional de museus. In: NASCIMENTO JUNIOR, J.; CHAGAS, M. S. (org.). Política nacional de museus. Brasília: MinC, 2007. p. 12-41.

PEREIRA, S. G. Arte no Brasil no século XIX e início do XX. In: OLIVEIRA, M. A. R.; PEREIRA, S. G.; LUZ, A. A. História da arte no Brasil: textos de síntese. Rio de Janeiro: Ed. UFRJ, 2010. p. 65-109.

PINTO, L. F. Rômulo Maiorana ainda é poderoso, mas não tanto. Adital: Notícias da América Latina e Caribe, 2013. Disponível em: http://site.adital.com.br/site/noticia. php?lang=PT\&cod=75795. Acesso em: 13 dez. 2015.

PIZARRO, A. Amazônia: as vozes do rio, imaginário e modernização. Belo Horizonte: Ed. UFMG, 2012.

POMIAN, K. Colecção. In: ENCICLOPÉDIA EINAUDI. Porto: Imprensa Nacional/ Casa da Moeda, 1984. p. 51-86. QUEIROZ, A. O dois mil e quatorze do Arte Pará. In: MACHADO, V. L. (org.). Arte Pará 2014: ano 33. Belém: Fundação Rômulo Maiorana, 2015. p. 8-9.

SANTAMARINA CAMPOS, B. Antropología y medio ambiente: revisión de una tradición y nuevas perspectivas de análisis en la problemática ecológica. AIBR: Revista de Antropología Iberoamericana, v. 3, n. 2, p. 144-184, 2008.

SARLO, B. Modernidad y después: la cultura en situación de hegemonía massmediática. Alteridades, v. 3, n. 5, p. 51-58, 1993.

SCHMIDT, R. T. Pensamento-compromisso de Homi Bhabha: notas para uma Introdução. In: COUTINHO, E. F. (org.). O bazar global e o clube dos cavalheiros ingleses: textos seletos de Homi Bhabha. Rio de Janeiro: Rocco, 2011. p. 13-61.

SILVEIRA, F. L. A. A paisagem como fenômeno complexo: reflexões sobre um tema interdisciplinar. In: SILVEIRA, F. L. A.; CANCELA, C. D. (org.). Paisagem e cultura: dinâmicas do patrimônio e da memória na atualidade. Belém: Ed. UFPA, 2009. p. 71-83.

TEDLOCK, D. A tradição analógica e o surgimento de uma antropologia dialógica. Anuário Antropológico/85, Brasília, p. 183-202, 1986.

ULLOA, A. Concepciones de la naturaleza en la antropología actual. In: PRATS, S. T. (coord.). Ecología y paisaje: miradas desde Canarias. La Orotava: Fundación Canaria Orotava de Historia de la Ciencia, 2009. p. 213-233.

Recebido: 16/01/2018 Aceito:29/11/2018 | Received:1/16/2018 Accepted: 11/29/2018

Esta obra está licenciada com uma Licença Creative Commons - Atribuição 4.0 Internacional This work is licensed under a Creative Commons Attribution 4.0 International License. 